\title{
Strengthening Islamic character through Mathematics learning
}

Muhammad Istiqlal \& Jumadi

IAIN Salatiga

SMA Negeri 2 Yogyakarta

m.istiqlal@iainsalatiga.ac.id

DOI: $10.18326 /$ mudarrisa.v9i2.188-207

\begin{abstract}
The concept of mathematics learning which is integrated with Islamic character education is still limited; this is one of logical reasons why this research is conducted. The basic motivation of carrying out this research is to describe a concept of mathematics learning which is contextualized with Islamic character education. This research aims at describing concept of mathematics learning which is integrated with Islamic character education. This research uses a qualitative approach by emphasizing its analysis on the comparative inference process as well as on phenomena relationship dynamics observed by using scientific logic. Qualitative research is an approach that produces descriptive data in the form of written words from observed people that are not written in terms used in quantitative research. Research method used in this study is case study in which the researcher is trying to find out how the process of strengthening Islamic character through mathematics learning. This research was carried out at MA Nurul Ummah Kotagede Yogyakarta which has innovatively implemented mathematics learning using various methods through interactive learning multimedia which is integrated with strengthening Islamic character. Research finding showed that strengthening Islamic character through mathematics learning at MA Nurul Ummah is integrated into several aspects, namely learning methods, learning materials, and all aspect directly related to learning process in the classroom including putting statement of honesty on the answer sheet and giving reward and punishment to students.
\end{abstract}

Keywords: strengthening character, Islamic character, mathematics learning 


\section{INTRODUCTION}

The rise of juvenile delinquency becomes social issue which is quite disturbing. This issue disturbs not only Muslims but also non-Muslim community. This case is reinforced by the result of a survey conducted by department of birth control, woman empowerment and child protection. The survey showed that in 2016 the level of juvenile delinquency increased dramatically when compared with previous year, more than $2 \%$. Further information is also explained in another survey result that factors contribute to the issue is the effect of environment and gadget. The environment in this case includes family, community, friendship and school environments.

Education plays primary rule in reducing the level of juvenile delinquency. Positive character can be embedded correctly and appropriately through education. Students can get an adequate understanding of positive characters that must be possessed by a person to build a good relationship with global society. The materials presented in the class should be integrated with positive values in order to build strong characters to students. By inculcating these positive characters, they will have a good and strong personality which is not easily influenced by deviant characters.

Primary and secondary education is very potential to serve as a place to inculcate positive character. According to Piaget's theory of cognitive development students at elementary and secondary education level are a formal operational stage, and at that stage one starts thinking 


\section{Mudarrisa: Jurnal Kajian Pendidikan Islam, Vol. 9, No. 2, 2017}

conceptually and hypothetically. Thus, abstract concepts are acceptable for learners at that stage.

The character discussed in this study is Islamic character as actualized by Prophet Muhammad SAW. In theory of Islamic education, character education has been implemented since 15 centuries ago. Character education is the main mission of Prophet Muhammad in preaching Islam, and he is the one who has a great character. This is in accordance with the word of Allah in Surah al-Qalam verse 4 which means: "..... and indeed you have truly virtuous character." Character education in Islam is similar to moral education and it is also the purification of soul and human character to be a pious human being. Character education requires humans to be virtuous like Prophet Muhammad SAW as the example for mankind.

Character education ontologically is an educative collaborative effort of three aspects namely knowledge, feeling and deed. Johansyah (2011) said in his research that the goal of character education is Islam is to shape true Muslim's character based on al-Qur'an, namely Muslim's characters that have good behaviour, devotee, muttaqin, mu'min, ulul albab and prophetic characters. It is explained in more detail that there are various approaches that can be identified related to character education or moral education, those are 1) theocentric approach, 2) anthropological approach, 3) historical approach, 4) personality approach, 5) philosophical approach, and 6) psychological approach. In addition, character education can be done using several methods such as advice, speech and dialogue. To 


\section{Mudarrisa: Jurnal Kajian Pendidikan Islam, Vol. 9, No. 2, 2017}

form feeling aspect, it can use parable and tarhib methods. Meanwhile, to form aspect of act, it can use habituation and example methods.

Kurniati (2013) states that concept of character education in Indonesia is a value education, namely noble values education that comes from Indonesian culture for the purpose of guiding personality of young generation which includes three aspects; moral knowledge, moral attitude and moral behaviour. The concept of Islamic education can be an alternative solution in inculcating positive character to students. The concept of education in question is a guidance given to a person in order to develop optimally in accordance with Islamic teaching that includes aspect of body, mind and the heart of students. Character education in Indonesia that includes moral knowing, moral feeling and moral acting, its educational purpose includes three aspects, namely physical, spiritual, and intellectual.

Sumardyono (2004: 12) asserts that the object of mathematics is social, cultural, and historical meaning that mathematics and its learning are common property of all people. No matter how primitive the community is, mathematics is part of its culture. Therefore, mathematics is universal. Mathematics was born from a long, historic journey in human life. Thus, it is possible if mathematics is contextualized with Islamic character education. This is because mathematics can reach social, cultural and historical aspects, including Islamic character education.

Mathematics has great potential to affect learners' mindset. Decision-making theory, probability theory, and other theories encourage 
students to build the right mindset. In addition, mathematics is a subject with the longest duration of time in a week as compared with other subjects. This makes mathematics have power to infiltrate the values of tolerance to students. In addition, students realize that mathematics is an evitable subject they must learn. Thus, mathematics can be a means to inculcate Islamic character since it is a compulsory subject learned by students.

Based on the analysis above, the researchers were interested in describing the concept of mathematics learning which is integrated with Islamic character education at MA Nurul Ummah Kotagede. Nowadays, this concept is still rarely used. For this reason, the researchers were trying to describe the concept of mathematics learning which is contextualized with Islamic character education.

\section{RESEARCH METHOD}

This is a qualitative research. This study emphasizes its analysis on comparative inference process as well as on the analysis of phenomena relationship dynamics observed using scientific logic. Qualitative research is an approach that produces descriptive data in the form of written words from observed people that are not implemented in terms used in quantitative research. Qualitative research is intended to figure out phenomena about what students experience holistically such as behaviour, perception, motivation and action by means of describing in the form of 
written words and language, to special context by utilizing scientific methods. (Moleong, 2012: 6)

Research method used in this research is a case study. In this study the researchers are trying to find out the process of strengthening Islamic character through mathematic learning at MA Nurul Ummah Kotagede. Robert K. Yin (2011: 18) explains the concept of case study as an empirical inquiry that investigates phenomena in a real-life context when the boundary between phenomena and context are unclearly visible. Case study focuses more on answering question words of "how" and "why".

The researchers collected the data and prepared lesson plan of mathematics which is able to integrate Islamic character, and applied the lesson plan in such a way. This study is also trying to describe about how to strengthen Islamic character to students through mathematics learning. Technique of analyzing date used in this study is descriptive qualitative analysis. This analysis is able to expose the result systematically and comprehensively.

\section{DISCUSSION}

\section{Character Education}

The law of education no. 20, 2003 defines education as conscious and planned effort to create learning atmosphere and learning process so that the students are actively able to develop their potential in order to have spiritual power, self-control, personality, intelligence and noble character needed for community, nation and themselves. Soyomukti (2010: 27) 


\section{Mudarrisa: Jurnal Kajian Pendidikan Islam, Vol. 9, No. 2, 2017}

asserts that the most considerable aspects in education are awareness, enlightenment, empowerment, and behavioural change. Furthermore, Poerbakawatja (1982: 257) argues that all effort and deed from older generation to divert knowledge, experience, and skill of young generation as an effort to prepare their life function both physically and spiritually is called education. Education is a process of building character, and it implicitly means education is process of building behaviour related to any positive moral (Muslich, 2011: 70).

According to Indonesian dictionary, the word character is defined as nature, psychological traits and morality which distinguish a person from another (Pusat Bahasa Depdiknas, 2008: 682). A person who has character can be interpreted as the one who possesses personality, morality, behaviour and mind. Lickona (1991: 51) defines character as a reliable inner disposition to respond to situation in a morally good way. Then he adds the explanation that character so conceived has three interrelated parts: moral knowing, moral feeling and moral behaviour. In other words, character refers to knowledge, behaviour, motivation and skill. The phenomenon of moral degradation is now awful. Some good characters such as honesty, truth, justice and mutual assistance now have been covered by corruption, fraud, oppression and torture, taking ones' right and other immoral acts (Nata, 2003: 197).

Character is moral or behaviour as characteristics to identify a person. The element of character consists of impulses, instincts, habits, tendencies, feeling, emotion and will (Mujib, 2006: 45). Allport in 


\section{Mudarrisa: Jurnal Kajian Pendidikan Islam, Vol. 9, No. 2, 2017}

Narwanti (2011: 2) explains that character is a dynamic organization of individual psychological and physical system that determines specific behaviour and thought of person and leads to human behaviour. Character is not solely personality since it is basically a priceless personality. Imam Ghozali says that character is closer to moral; it is humans' spontaneity in action or doing things, so when those mentioned appear they don't need to think of it again (Muslich, 2011: 70).

Character is universal values of human behaviour that includes all human activities in relation to god, environment, other people or themselves which is embodied in thought, attitude, feeling and deed based on religious norms and customs (Maruki, 2012: 4). All those definitions of character are identical with personality and moral. Personality is a characteristic of a person that comes from the formations obtained from the childhood, or it might be innate (Koesoema, 2007: 80).

Integrated character education in learning can be realized with the introduction of values, the importance and internalization of values into students' daily life through teaching and learning process whether inside or outside classrooms. Thus, the students will master not only the competence of targeted material but also the goal designed for students in order to recognize and internalize behavioural values (Kemendiknas, 2010: 2). According to Thomas Licona (Q-Anees \& Hambali, 2008: 99), character building is the education to shape one's personality through character education, whose results are real and visible in humans' daily practices such as honesty, behaviour, responsibility, respecting rights of 
other, hard work etc. Character education is essentially the integration among intelligence, personality, and noble character.

There are so many values that can be developed in students, yet inculcating these into students is hard duty to do. Therefore, it is necessary to select and prioritize certain values to be inculcated to students. The main values should be from points of passing standard, namely religiosity, honesty, intelligence, and care. Human's religiosity can be interpreted as thought and action based on Islamic teaching. Honesty is a behaviour which is based on an effort to establish a trusted person in words, action and work. Intelligence is ability to undertake a duty precisely and fast. Tenacity is an attitude of unyielding when encountering some difficulties for the sake of reaching goals. Democracy is interpreted as a way of thinking, behaving and acting that assesses the rights of others. Caring is an effort to prevent and repair deviation and damage (human, nature and order) happening around (Kemendiknas, 2010: 9). These six values are inculcated through all subjects with more intensive inculcation than other subjects.

\section{Islamic Character}

Character education is a fundamental issue in Islam. Islam sees that one's identity is essentially a moral. Moral is a real portrait of one's inner condition. Allah is clearly defining a noble person. The noble man in this case is those who believe in good. Then the noble man in the eyes of god is not measured by descent and treasure, but the glory which inwardly has 


\section{Mudarrisa: Jurnal Kajian Pendidikan Islam, Vol. 9, No. 2, 2017}

the quality of faith and is able to actualize it in the form of attitude, words and deeds (Surah al-Hujarat 49: 13).

"O men! Behold, We have created you all out of a male and a female, and made you into nations and tribes, so that you might come to know one another. Verily, the noblest of you in the sight of god is the one who is most deeply conscious of him. Behold, God is all knowing, all aware."

Character in Islam is more familiarly called morality, personality and attitude of a person that can be seen from his behaviour, way of speaking and others which exist in human personality as identity which cannot easily be changed. To know the term of character in Islam, we need to understand about the definition of moral according to scholars as quoted by Syukur (1999: 162) as follows: 1) Ibn Maskawih, moral is physical condition which encourages a person to do the things without thinking and considering in advance; 2) Ibn Qayim, moral is a temper or attitude which is possessed by all humans; 3) Al-Ghazali, moral is a character or attitude embedded in the soul.

Belief is built on the basis of six beliefs or commonly known as six pillars of faith. Syaria means all religious rules set by Allah for all Muslims prescribed either by al-Qur'an or by tradition of prophet (Musal, 1988: 131). According to Mahmud Syaltut, syaria is defined as the rules prescribed by Allah so that humans actualize it in dealing with their god, friends, all humans and the universe (Syaltut, 1966: 12). While moral means the motion of soul that leads human to do the things without stressing the mind. This is an opinion promoted by Ibnu Maskawih. 


\section{Mudarrisa: Jurnal Kajian Pendidikan Islam, Vol. 9, No. 2, 2017}

Anther scholar, Ghozali defines moral as permanent nature in the human soul that might result the deeds easily (Djatmika, 1996: 27).

Moral is one of the three basic frameworks of Islamic teachings that have a very important position in addition to the other two basic frameworks. Moral is the essence resulted from the process of actualizing aqidah and sharia. Like a building, moral is the perfection of the building itself after the foundation. So, it is impossible to create a moral in a person if he doesn't have good moral and syaria (Marzuki, 2012: 2).

There are two systems of morality prevailing in society, namely religious moral and secular moral. Islam requires the development of good moral whose behavioural patterns are based on iman, islam and ihsan. Faith as al-quwah al-dakhiliyah, inner power that guides human to continuously get close to Allah and muhasabah (to calculate) the deed that will, being or has been done. Ubudiyah is the path to realize the goal of moral. The first step to internalize the moral is by measurement of worship to Allah. Character will not appear in behaviour without following the rules prescribed by Allah SWT (Hawa, 1977: 72).

Secular morality is a system created or as a result of human's thought based on secular sources from the law that purely exists in life, human intuition, experience and human character (Ismail, 1998: 181). The system of this morality comes from the existence of various social problems that occurred in the past. The emergence of social problems affects the existence of stigma about human's bad and good morality then 
appears the different dimension. For example, hedonism emphasizes on happiness, enjoyment, and worldly delights (Marzuki, 2012: 7).

\section{Mathematics Learning}

James and James (in Suherman, 2001: 16) define mathematics as a logical science of the form, structure, magnitude, and concepts associated with one another with a large number that is divided into three fields, namely algebra, analysis and geometry. Permendiknas No. 222006 states about the content standard that the goals of mathematics learning for students at all level of education are: 1) Understanding the concept of mathematics, explaining the interrelation among concepts and applying those concepts or algorithms flexibly and efficiently and still focusing on the problem solving; 2) Using logical way on patterns, performing mathematical manipulation in generalizing, compiling evidence, or explaining mathematical idea and statement; 3) Solving the problem covering the ability to understand the problems, design mathematical model, complete model, and interpret solution; 4) Communicating ideas with symbols, tables, charts or other media to clarify the situation or problem; and 5) Having sense of appreciation of the use of mathematics in life that it has curiosity, attention and interest in learning mathematics, as well as a tenacious attitude and confidence in problem solving.

Some definitions or expressions are promoted so that the readers are able to easily catch the point of view of mathematicians. People who are interested in number see mathematics from the number perspective. 
Other people are more attentive to the structure, knowing mathematics from its structure. And some others are more interested in mindset or systematics, then knowing mathematics from its systematics. Finally, there are lots of various definitions of mathematics, and it affects that there is no single definition which is approved by mathematicians.

Mathematics learning is an activity to modify various condition which are directed to reach the goal through intellectual activities so that the abstract and socio-cultural object of mathematics can be conveyed, and the objectives of mathematics learning can be achieved (Sumardyono, 2004: 12). Before math learning is started, there must be decision of some goals so that the intellectual activities in learning process runs smoothly. In general, the goal of mathematics learning in Indonesia emphasizes on solving of mathematical problems.

\section{RESEARCH FINDINGS}

Mathematics learning carried out at MA Nurul Ummah Kotaged is innovative math learning. The method of learning used is various and using interactive learning multimedia. Strengthening of Islamic character integrated with math learning system is performed at school. Strengthening Islamic character through math learning performed at MA Nrula Ummah Kotagede is integrated with several aspects, namely learning methods, subject material, and all things related to teaching learning process in the classroom such as writing hones statement on the answer sheet, and giving reward and punishment to students. 


\section{Mudarrisa: Jurnal Kajian Pendidikan Islam, Vol. 9, No. 2, 2017}

\section{Learning Methods}

Mathematics can be taught with various methods. Flexible mathematics encourages teacher to freely give expression in using methods. The learning methods used should be able to be integrated with positive characters. One of them is Team Game Tournament (TGT) method. In this method, students are divided into several groups, and then teacher gives them cards containing some questions to answer. Teacher writes the score obtained each group on the board. This is intended to perform honest and transparent attitudes.

After that, each group is given card containing some questions according to the number they take, they work together to solve the problems given. In this activity, the students are highly motivated to win their group by solving the problems they receive. This learning process will teach students the attitude of responsibility and hard work.

The activity is then continued with tournament, it is to compare the students in a group. Three groups that have the highest ability are united in one table. The attitude of honesty is clearly illustrated at this stage, so each student feels confident because they meet with a matched opponent. The value of justice is an important point at this stage.

This is a brief illustration of how to integrate the method of learning mathematics with anti-corruption values. The values of anticorruption should be explicitly expressed by teacher so that the students can easily grasp the meaning of teacher's teaching using a particular method other than to deliver the subject material interestingly. There are 
lots of math learning methods that can be a means to convey the values of anti-corruption to students so that they will have the character of anticorruption.

\section{Learning Materials}

Inculcating Islamic character through math learning can be done by integrating the math material during teaching learning process in the class. The process of delivering material varies depending on teacher's creativity. Some of the materials that can be integrated in inculcating Islamic character are as follow:

Mathematical Logic Material. Mathematical logic presents a causal relationship of several premises. It can be presented thematically. All statements and premises are entirely about anti-corruption. For example:

P: students who cheat will be shunned by their friends (true)

Q: students who cheat will be scolded by teacher (true)

These $\mathrm{P} \& \mathrm{Q}$ statements can be linked in conjunction relation; the following is the table of truth conjunction:

Table 1. Table of Truth Conjunction

\begin{tabular}{|c|c|c|}
\hline $\mathrm{p}$ & $\mathrm{q}$ & $\mathrm{p} \wedge \mathrm{q}$ \\
\hline $\mathrm{T}$ & $\mathrm{T}$ & $\mathrm{T}$ \\
\hline $\mathrm{T}$ & $\mathrm{F}$ & $\mathrm{F}$ \\
\hline $\mathrm{F}$ & $\mathrm{T}$ & $\mathrm{F}$ \\
\hline $\mathrm{F}$ & $\mathrm{F}$ & $\mathrm{F}$ \\
\hline
\end{tabular}

The statements above can be interpreted as follows: 1) Students who cheat will be shunned by friend and scolded by teacher. This premise 
is true because everyone agrees that students who cheat will be shunned by friend and scolded by teacher; 2) Corruptor get a social punishment, yet they do not get severe punishment. This premise is false because people who corrupt must get severe punishment; 3) Corruptors do not get social punishment, yet they get severe punishment. This premise is false because people who corrupt must get also get a social punishment for their deed; 4) Corruptors get social punishment, yet they still do not get severe punishment. This premise is false since people who corrupt must get both social and severe punishments. Then in sub-chapter the implication can be implemented as follows:

$\mathrm{P}$ : corruptor is a thief of people's money

Q: corruptor gets severe punishment

The statement can be expressed in the relation of implication and can be expressed its truth value: 1) If corruptor is a thief of people's money, he will get severe punishment then. This premise is true because a corruptor deserves a severe punishment; 2) If corruptor is a thief of people's money, he won't get severe punishment. This premise is false because a person who corrupts must get severe punishment. 3) If corruptor is not a thief of people's money, he then does not get severe punishment. This premise is true because if a person is not a corruptor, he doesn't need to be punished.

Through this thematic example, students can find the truth table of an implication. Besides the thematic example of anti-corruption attitudes, it will provide students an understanding that corruption is a 
crime, and they must stay away from all behaviours that may lead to corruption.

\section{Teaching-Learning Process in Classroom}

In addition to integrating Islamic character with learning materials and learning methods, Islamic character can also be integrated through teaching and learning activities in the classroom. With this third method, teacher is required to create learning innovation that provides Islamic character in mathematics learning in the classroom. Skinner's theory also supports this third method. In brief, Skinner explains that repeated behaviour will shape a habit. The following are some ways we can do to familiarize attitude of anti-corruption:

Statement of honesty on the answer sheet of math

Teacher may prepare an answer sheet that has been set. The answer sheet can be set by providing column for students' statement that the result of work is purely done by them, and the statement is signed by students. By doing so, the students will familiarize with honest attitude and they tend to be honest when doing the test or quiz.

Giving punishment when coming late

It is necessary to make a deal about students who come late without logical reason must be punished. Students are given understanding by teacher that being late is just wasting time, and it disturbs other students in teaching and learning process, it even disturbs the teacher. So, there must be social punishment for anyone who comes late for entering the class. 
The prevailing social punishment should be agreed by all students in the classroom. The function of teacher in this case is just as protector who is in charge of the prevailing punishment. This method is effective for students and they will be aware that reducing time is useless, and it can also be categorized into corruption, namely time corruption. Besides, those bad attitudes can harm even infect other students. In other words, corruption may endanger you even others. It means that negative attitude will harm yourself and other people.

There are lots of ways can be prepared by math teacher to inculcate Islamic character to students. It depends on how the teacher sets the math learning atmosphere so that it can be integrated with Islamic character. As a teacher, we have responsibility to prepare you generation to be candidate of future leader of nation. By preparing young generation who has Islamic character then it will born some leaders who have Islamic character.

\section{CONCLUSION}

The inculcation of Islamic character can be done through several ways; one of them is by integrating it in math learning. Mathematics as the core of subject has great power to influence student's character. There are lots of methods to integrate mathematics with Islamic character. It can be done through learning method, learning materials, and teaching learning process in class. We can build some positive characters such as honest, care, independent, discipline, responsible and others through learning 
methods. One of effective methods that can be used to integrate math with Islamic character is Tame Gams Tournament (TGT).

Math learning material can be added some behaviours that reflects caustic Islamic values. For example, math material can be presented in the form of thematic material. We can invite students to draw the conclusion about the behaviours that deviate from Islamic teaching reported in social media by using logic mathematics. We can also present other material instead of mathematics to inculcate Islamic character. It depends on how we explore math material in class. In teaching learning process, we can ask students to familiarize with attitude of anti-corruption. One of them is by giving statement of honesty on the answer sheet, and giving punishment to those who come late. With this habit, the students are expected to always build character of discipline and anti-corruption.

\section{References}

Amin, A. (1995). Etika (ilmu Akhlak). Terj. Oleh Farid Ma'ruf. Jakarta: Bulan Bintang.

Djatmika, R. (1966). Sistem Etika Islam (Akhlak Mulia). Jakarta: Pustaka Panjimas.

Hawa, S. (1977). Al-sslam. Maktabah Wahdah

Ismail, F. (1988). Paradigma Kebudayaan Islam. Yogyakarta: Titihan Ilahi Press.

Johansyah. (2011). Pendidikan Karakter dalam Islam; Kajian dari Aspek Metodologis. Jurnal Ilmiah Islam Futura Volume XI, No.1. hal 85103

Koesoema, D. (2007). Pendidikan Karakter: Strategi Mendidik Anak di Zama Global. Jakarta: Grasindo. 
Marzuki. (2012). Pendidikan Al-Quran dan Dasar-dasar Pendidikan Karakter dalam Islam (makalah disampaikan dalam Seminar dengan tema Penanaman dan Pengembangan Karakter Muliah pada Anaka-anak melalui Melalui Pendidikan Al-Quran). Yogyakarta: P4TK Seni Budaya

Musa, M. Y. (1988). Islam Suatu Kajian Komprehensif. Terj. A. Malik Madany dan Hamim Ilyas. Jakarta: Rajawali Press.

Moleong, L.J. (2012). Metodologi Penelitian Kualitatif Edisi Revisi. Bandung: PT Remaja Rosdakarya.

Nata, A. (2003). Manajemen Pendidikan, Menagatasi Kelemahan Pendidikan Islam di Indonesia. Cet III. Jakarta: Prenada Media Grup.

Lickona, T. (1991). Educating for Character: How Our School Can Teach Respect and Responsibility. New York: Bantam Books.

Q-Anees, B \& Hambali, A. (2008). Pendidikan Karakter Berbasis Al-Qur'an. Bandung: Simbiosa Rekatama Media.

Syaltut, M. (1966). Al-Islam 'Aqidah wa Syari'ah. Kairo: Dar al-Qalam. Cet. III

Syukur, M. A. (2010). Studi Akhlak. Semarang: Wali Songo Press.

Yin, R. K. (2011). Studi Kasus:Desain dan Metode. Jakarta:PT.Rajagrafindo Persada. 